\title{
Budaya Organisasi Sebagai Strategi Pengelolaan Konflik Dalam Perusahaan Keluarga di PT. Book Mart Indonesia
}

\author{
Dian Rokhmawati ${ }^{1}$, Rachma Yuliana ${ }^{2}$ \\ Universitas Wishnuwardhana Malang \\ Email : Yoke.barokahunited@gmail.com
}

\begin{abstract}
Conflicts in family companies cannot be avoided, given that there are stronger emotional factors in employee family ties that are integrated with logic and rational targets in doing business. For this reason, a conflict management strategy is needed that makes conflict a supporter of the strength of the family business. This study aims to: 1) Determine the extent to which conflict affects the activities and business performance of the company, and 2) how the strategy of PT. Book Mart Indonesia in managing conflicts that occur. The approach used in this research is qualitative, while the type of research is descriptive. The determination of the source in this study was carried out by means of purposive sampling. Two types of data used are primary data and secondary data. Data collection procedures used were interviews and documentation. The results showed that the root causes of conflict in PT. Book Mart Indonesia (PTBMI) is a company that is empty of family values, no organizational culture and weak corporate vision and mission. Conflicts that occur (media.neliti.com), for example misunderstandings related to information, decisions related to project making and decisions about task shifting / division of labor. This conflict is caused by the absence of Standard Operating Procedures (SOP), the absence of clear company rules such as an administrative system (recording), professional financial management to strengthening brands in the market. This conflict has a major impact, with indications of high employee turnover and a decline in company performance.
\end{abstract}

Keywords : Conflict, Family Company, Organizational Culture, Strategy, Management.

Abstrak

Konflik dalam perusahaan keluarga merupakan hal yang tak bisa dihindari mengingat adanya faktor emosi yang lebih kuat terdapat dalam ikatan karyawan keluarga yang terpadu dengan logika dan target rasional dalam bisnis. Dengan demikian diperlukan strategi pengelolaan konflik yang justru menjadikan konflik sebagai pendukung kekuatan bisnis keluarga. Penelitian ini bertujuan untuk: 1) Mengetahui sejauh mana konflik mempengaruhi aktivitas dan kinerja bisnis perusahaan, dan 2) bagaimana strategi PT. Book Mart Indonesia dalam mengelola konflik yang terjadi.Pendekatan yang digunakan dalam penelitian ini adalah kualitatif, sedangkan jenis penelitiannya adalah deskriptif. Penentuan narasumber dalam penelitian ini dilakukan dengan cara purposive sampling.Jenis data yang digunakan ada dua yaitu data primer dan data sekunder. Prosedu rpengumpulan data yan gdigunakan adalah wawancara dan dokumentasi. Analisis data yang digunakan adalah dengan cara deskriptif, sedangkan untuk uji validasi menggunakan triangulasi sumber. Temuan peneliti menunjukkan bahwa akar persoalan terjadinya konflik dalam PT. Book Mart Indonesia (PTBMI) adalah kosongnya perusahaan dari nilai-nilai keluarga, tidak ada budaya organisasi serta lemahnya visi misi perusahaan. Konflik yang terjadi misalnya kesalah pahaman terkait informasi, keputusan terkait pengambilan proyek dan keputusan tentang pengalihan tugas/pembagian kerja. Konflik ini disebabkan oleh tidak adanya Standar Operational Procedure (SOP), tidak adanya aturan perusahaan yang jelas seperti sistem administrasi (pencatatan), pengelolaan keuangan profesional sampai penguatan brand di tengah-tengah pasar. Konflik ini berdampak besar dengan indikasi turn over karyawan yang tinggi serta menurunnya kinerja perusahaan.

Kata kunci: Konflik, Perusahaan Keluarga, Budaya Organisasi, Strategi, Pengelolaan.

(C) 2021 Jurnal Riset Inspirasi Manajemen dan Kewirausahaan

\section{PENDAHULUAN}

Para wirausaha selalu menjadi ujung tombak bagi kemajuan ekonomi sebuah negara. Di negara- negara yang relatif maju perekonomiannya selalu bertebaran parawirausaha yang tangguh. Mereka inilah sebenarnya pencetak keajaiban ekonomi. Para wirausaha ini selain mempunyai ide inovatif 
juga mempunyai kemampuan merealisasikan gagasan-gagasan yang ada di benak mereka. Langkah yang mereka tempuh untuk mewujudkan ide, tentunya adalah membuat sebuah badan usaha. Agar dapat merealisasikan ide sesuai keinginannya, maka perusahaan harus berada dalam kendalinya. Dan ketika idenya terealisasi, yang muncul adalah perusahaan keluarga (Susanto, 2010)

Price Waterhouse Cooper $(P w C)$, sebuah perusahaan audit dari Amerika Serikat melakukan survei mengenai bisnis keluarga di Indonesia. Hasil survei tersebut menyebutkan bahwa lebih dari 95 persen perusahaan Indonesia adalah perusahaan keluarga dengan omset sekitar US\$ 5 - 10 juta dan total kekayaan mencapai US\$ 134 miliar atau sekitar 25 persen dari Produk Domestik Bruto (PDB) Indonesia. (Ceostars.net/95-persenperusahaan-di-indonesia-milik-keluarga, 24 Agustus 2016). Data Indonesian Institute for Corporate and Directorship(IIDC, 2010) menyatakan bahwa lebih dari 95 persen bisnis di Indonesia merupakan perusahaan yang dimiliki keluarga. Hal tersebut membuktikan bahwa aktivitas bisnis keluarga telah berperan besar dalam pembangunan ekonomi nasional. (journal.uinjkt.ac.id) Ketika negara ini mengalami krisis di tahun 1998 dan 2008 yang menyebabkan kondisi perekonomian terpuruk, perusahaan keluarga menunjukkan posisinya sebagai pendukung ekonomi nasional. (Simanjuntak, 2010).

Terdapat banyak perusahaan keluarga di indonesia yang berbentuk persekutuan firma atau persekutuan komanditer yang memiliki potensi yang teramat besar untuk berkembang. Perusahaanperusahaan tersebut termasuk usaha mikro, kecil dan menengah (UMKM) (eprints.undip.ac.id) yang mampu memainkan peran tersendiri dalam rangka memperkuat perekonomian nasional terutama dalam hal penyerapan tenaga kerja. Menurut data Statistik Perbankan Indonesia, peran dan kontribusi UMKM cukup besar dalam perekonomian Indonesia tahun 2017. UMKM menjadi penyedia lapangan kerja terbesar yaitu 96,7\%. UMKM juga menyumbang sekitar $61,41 \%$ terhadap pembentukan Produk Domestik Bruto (PDB). (www.bpkp.go.id) Selain itu, UMKM juga berkontribusi terhadap investasi sebesar 56,2\% (Kementrian koordinator bidang perekonomian Republik Indonesia/SPI, 2017).

Sebagai perusahaan yang dikendalikan oleh keluarga, tentu perusahaan keluarga tidak lepas dari berbagai persoalan. Temuan PwC menyebutkan bahwa isu utama yang berpotensi konflik adalah perekrutan karyawan, re-organisasi perusahaan (isu putra mahkota), ketersediaan keuangan, pengendalian arus kas dan perbedaan konsep manajerial usaha. Sebagai akibatnya perusahaan keluarga mengalami kemerosotan bahkan seringkali tutup karena konflik berkepanjangan di internal keluarga.

\section{KAJIAN LITERATUR}

\section{Konsep Perusahaan Keluarga (Family Business/Family Firm)}

Dalam hukum perdata (private law), bisnis keluarga tidak didefenisikan secara khusus. Tetapi, pengertian bisnis keluarga bisa dirunut dari pengertian keluarga (family) dan hubungan kekeluargaan atau pertalian darah menurut hukum. Menurut Stefan S. Handoyo (2010), family is a community of persons headed by a man and women, united in marriage and theiroffspringsaswell as relatives to the third or fourth degree of consanguinity. Dengan begitu, bisnis keluarga atau family business merupakan bisnis yang dimiliki atau dikelola oleh sejumlah orang yang memiliki hubungan kekeluargaan baik suam-istri maupun keturunannya, termasuk hubungan persaudaraan. Definisi ini diperkuat lagi dengan definisi dari Dictionary of Law (2000) sebagai berikut: company where most of the shares are owned by members of the same family. (jurnalmanajemen.petra.ac.id) (Simanjuntak, 2011)

Mandl, 2008 dalam Hnatek (2015) menyatakan bahwa bisnis keluarga adalah cara tradisional melakukan bisnis di sektor swasta dan aktif di semua sektor ekonomi. Lambing dan Kuehl (2008) menyatakan bahwa bisnis keluarga adalah mayoritas kepemilikan yang dikendalikan oleh keluarga, dua atau lebih anggota keluarga secara langsung terlibat. Helmiatin dan Mulyana (2009) menyatakan bahwa bisnis keluarga adalah bisnis yang dilakukan secara teratur bersama keluarga. Partisipasi dari keluarga dapat memperkuat bisnis, ini karena anggota keluarga yang setia dan berdedikasi kepada perusahaan keluarga. Dewi dan Dewanto (2012) menyebutkan bahwa bisnis keluarga adalah bisnis yang diatur dan diorganisir dengan maksud untuk membentuk dan mengejar seorang pengusaha yang dikendalikan oleh anggota keluarga yang sama atau sejumlah kecil keluarga dengan cara memiliki potensi untuk terus berlanjut sepanjang generasi keluarga.

\section{Batasan Perusahaan Keluarga}

Susanto (2010) Dalam terminologi bisnis ada dua jenis perusahaan keluarga. Pertama adalah Family Owned Enterprise ( $F O E$ ) yaitu perusahaan yang dimiliki oleh keluarga tetapi dikelola oleh 
eksekutif profesional yang berasal dari luar lingkaran keluarga. Dalam hal ini keluarga berperan sebagai pemilik dan tidak meilibatkan diri dalam operasi di lapangan agar pengelolaan perusahaan berjalan secara profesional. Dengan pembagian peran ini anggota keluarga sebagai pemilik perusahaan dapat mengoptimalkan diri dalam fungsi pengawasan. Seringkali terjadi perusahaan keluarga tipe ini merupakan bentuk lanjutan dari usaha yang semula dikelola oleh keluarga yang mendirikannya. Jenis perusahaan keluarga yangkedua adalah Family Business Enterprise $(F B E)$ yaitu perusahaan yang dimiliki dan dikelola oleh anggota keluarga pendirinya. Baik kepemilikan maupun pengelolaannya dipegang oleh pihak yang sama, yaitu keluarga. Perusahaan keluarga tipe ini dicirikan oleh dipegangnya posisi-posisi kunci dalam perusahaan oleh anggota keluarga. Di Indoneia, kebanyakan perusahaan keluarga adalah FBE di mana para anggota keluarga menjadi pengelolanya. Dalam perjalanannya, seiring dengan tumbuh kembangnya perusahaan, dinamika dan tingkat kompleksitanya semakin tinggi. Dinamika yang semakin tinggi tentu saja menuntut kompetensi yang tinggi bagi pengelolaannya. Jika kebutuhan akan kompetensi ini tidak terpenuhi oleh anggota keluarga maka dibutuhkan suntikan tenaga dari luar lingkaran keluarga. Berangkat dari tuntutan semacam ini, tumbuh kembangnya perusahaan tidak jarang membuat perusahaan keluarga bermetamorfosa dari FBE menjadi FOE. Namun perubahan semacam ini di Indonesia prosentasenya masih kecil dan belum signifikan.

\section{Prinsip-prinsip Manajemen dalam Perusahaan Keluarga}

Prinsip (principle) atau basic point merupakan kaidah-kaidah atau nilai-nilai dasar yang diyakini setiap orang sebagai suatu kebenaran mutlak dan berlaku universal. Misalnya, kejujuran, transparansi dan keadilan merupakan prinsip-prinsip dalamperusahaankeluarga (family business) yang menggunakan Perseroan Terbatas (PT) sebagai bentuk badan usaha. Prinsip menurut Dictionary of Law (2000) disebut sebagai general rule atau the correct way to act. (jurnalmanajemen.petra.ac.id)

Simanjuntak (2011) menyebutkan prinsipprinsip bisnis keluarga. Pertama, prinsip kejujuran. Lewis Smedes (1983) dalam buku tulisan Alexander Hill berjudul Just Business berpendapat bahwa kejujuran (dalam bisnis) penting untuk tiga alasan,yaitu membangun kepercayaan mengembangkan masyarakat dan melindungi martabat diri. Tanpa komunikasi yang jujur dalam menjalankan bisnis keluarga, kepercayaan itu tidak mungkin ada. Jujur itu berlaku terhadap siapa saja baik di internal maupun eksternal kelaurga.

Kedua, prinsip keadilan, Seorang direksi, staf atau karyawan perusahaan yang tiba-tiba diberhentikan (dipecat) oleh pemilik perusahaan (owner) tanpa penjelasan yang jelas dari pihak manajemen, dan tanpa diberi kesempatan membela diri merupakan tindakan yang tidak adil. Pemecatan yang dilakukan tanpa alasan yang jelas merupakan bentuk perampasan hak sosial dan ekonomi pekerja. Demikian pula perlakuan diskriminatif manajemen perusahaan terhadap para pekerjanya, baik dalam hal karir maupun upah. (jurnalmanajemen.petra.ac.id)

Ketiga, prinsip kelestarian lingkungan hidup. Alexander Hill juga menggaris bawahi pentingnya tanggungjawab pebisnis terhadap masyarakat dan lingkungan hidup. Pemilik perusahaan tidak seharusnya berpikiran bahwa selama kegiatan bisnis mereka tidak memberi ancaman kepada masyarakat, pemilik bisnis bebas menggunakan tanah dengan semaunya. Jika terjadi perusakan atau pencemaran lingkungan maka, demi keadilan, perusahaan yang menyebabkannya membayar kompensasi atau ganti rugi yang wajar termasuk kepada masyarakat yang terkena dampaknya. Intinya, para pengusaha tidak patut mengambil keuntungan dari kerugian pihak lain. Keempat, prinsip keselamatan konsumen. Perusahaan yang menghasilkan produk-prduk yang merusak kesehatan wajib pula memberikan penggantian yang wajar kepada konsumen yang menggunakannya. Konsep menggunakan sumber daya sekecil-kecilnya untuk memperoleh keuntungan yang sebesar-besarnya (efisiensi) tidak boleh sampai mengorbankan keselamatan konsumen. (jurnalmanajemen.petra.ac.id)

\section{Konflik Dalam Perusahaan Keluarga}

Tumpang tindih peran dalam sistem bisnis dan keluarga, anggota keluarga mungkin lebih cenderung mengalami konflik. Artinya, di perusahaan keluarga, kekeluargaan dan bisnis begitu terjalin sehingga potensi perselisihan mungkin lebih besar daripada di non-keluarga perusahaan. Misalnya, persaingan antar saudara, perselisihan perkawinan, konflik identitas, dan masalah kepemilikan di antara anggota keluarga semuanya mencerminkan isu-isu terkait keluarga yang dapat berkontribusi terhadap konflik dalam bisnis keluarga (Eddleston, 2010). Selain sistem yang tumpang tindih ini, dinamika waktu dari hubungan keluarga juga berkontribusi pada manifestasi unik dari konflik dalam perusahaan 
keluarga. Artinya, karena setiap generasi baru anggota keluarga memasuki bisnis, dinamika yang ada dalam koalisi dominan kemungkinan akan berubah. Jadi, hubungan yang mapan, apakah menyenangkan atau penuh dengan konflik, dapat bergeser dan menjadi lebih kompleks seperti generasi baru anggota keluarga mulai bekerja di perusahaan keluarga. Akhirnya, bagaimana anggota perusahaan keluarga menanggapi konflik yang sedang berlangsung mungkin berbeda dari dalam pengaturan bisnis tradisional. Artinya, anggota keluarga sering sangat berkomitmen terhadap perusahaan keluarga mereka, yang meningkatkan biaya keluar (Eddleston, 2010).

Selain itu, anggota keluarga dapat tetap berada di perusahaan keluarga meskipun mengalami konflik yang dalam karena mereka takut meninggalkan perusahaan akan membahayakan warisan mereka atau peluang anakanak mereka di perusahaan keluarga. Kesetaraan dalam perusahaan keluarga juga dapat mendorong anggota keluarga untuk tinggal bersama perusahaan keluarga mereka meskipun ada konflik. Jadi, mungkin perlu bagi anggota keluarga untuk merekonsiliasi perbedaan mereka karena menghindari atau meninggalkan konflik di belakang tidak mungkin.

\section{Bentuk Konflik Keluarga}

Meskipun konflik tipikal mengandung konotasi negatif, para peneliti telah menyoroti bagaimana proses ini dapat menghasilkan efek positif dan negatif dalam perusahaan keluarga (Eddleston, 2010). Meskipun konflik memiliki potensi untuk menciptakan perselisihan dalam koalisi dominan, batas kohesi dalam keluarga dapat bermanfaat (Eddleston, 2008). Misalnya, konflik dapat membatasi kemungkinan bahwa koalisi dominan perusahaan keluarga mencapai konsensus sebelum waktunya (yaitu, groupthink). Artinya, daripada menetapkan solusi awal untuk tantangan yang dihadapi organisasi, konflik dapat mendorong anggota keluarga usia untuk menguraikan opini dan meningkatkan keterlibatan mereka dalam pengambilan keputusan dan perencanaan organisasional. Demikian juga, ketidaksepakatan dan diskusi semacam itu dapat menimbulkan kesadaran yang meningkat tentang informasi eksternal dan perubahan lingkungan yang dihadapi perusahaan keluarga. Terakhir, konflik dapat membatasi sejauh mana perusahaan keluarga bergantung pada satu generasi untuk memimpin organisasi (Eddleston, 2008). Artinya, perselisihan di antara anggota keluarga dapat memberikan kesempatan bagi generasi yang lebih muda untuk mengekspresikan pendapat mereka dan menjadi lebih terlibat dalam perusahaan keluarga. Salah satu pertimbangan utama dalam perusahaan keluarga. Salah satu pertimbangan utama keluarga adalah menentukan jenis konflik yang dialami. Para peneliti telah mengidentifikasi tiga bentuk utama konflik: konflik hubungan, konflik tugas dan konflik proses (de Wit, Greer dan Jehn, 2012; Loughry dan Amason, 2014). Konflik hubungan mengacu pada persepsi permusuhan pribadi atau ketidaksesuaian dan termasuk komponen emosional atau afektif (frustasi, jengkel, iritasi) (Eddleston, 2008; Jehn \& Mannix, 2008). Sebagian besar penelitian berfokus pada bentuk konflik ini, yang sering berkontribusi pada hasil negatif dalam perusahaan keluarga karena itu mengalihkan perhatian dan upaya anggota keluarga dari fungsi dan tanggung jawab produktif (Eddleston, 2008).

\section{Teori Sementara (Tentative Theory)}

Faktor utama konflik dalam perusahaan keluarga adalah adanya distrust. Achmad Sobirin, Ph.D. direktur Centre for Indonesian Family Business Studies FE UII menerangkan bahwa orang tua terkadang tidak bisa melepaskan begitu saja tanggung jawab perusahaan kepada anaknya. Hal ini disebut sebagai founder centrality. Orang tua kadang otoriter di dalam pengelolaan bisnisnya. Pertama karena orang tua merasa yang paling tahu, kedua karena ketika pensiun maka dia akan berpikir tidak ada pekerjaan selain mengelola bisnis keluarganya sendiri. Bisnis keluarga tentu tak lepas dari emosionalitas karyawan keluarga. Sehingga bertolak belakang dengan karakter bisnis itu sendiri yakni profesional dan transaksional. Maka penting bagi para pelaku usaha bisnis keluarga untuk menyeimbangkan antara kepentingan perusahaan dengan kepentingan keluarga.

Mengikuti kajian teori sebagaimana diacu menurut uraian di atas maka berikut ini dikemukakan pra/konsep map of problem/tentative theory yang bersifat spekulatif dengan konstruk gambar di bawah ini:

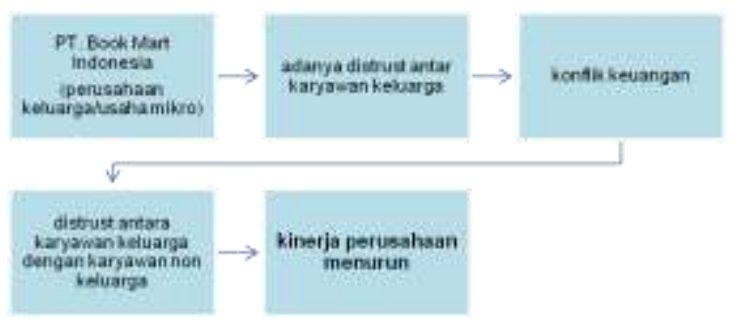




\section{METODE PENELITIAN}

\section{Jenis Penelitian}

Penelitian ini dilakukan dengan (docplayer.info) pendekatan kualitatif (sitiroikhanah.blogspot.com) sebagaimana Bogdan dan Taylor dalam Leksono (2013:59) mendefinisikan penelitian kualitatif sebagai prosedur penelitian yang menghasilkan data deskriptif berupa kata-kata tertulis atau lisan dari orang-orang atau perilaku yang diamati. Penelitian ini menggunakan jenis deskriptif karena ingin mengkaji fenomena konflik yang terjadi di perusahaan keluarga dengan melihat sumber konflik, sejauh mana konflik dapat mempengaruhi kinerja perusahaan dan bagaimana konflik diselesaikan.

\section{Subyek Penelitian}

Penelitian ini dilakukan pada perusahaan keluarga yang bergerak di bidang percetakan, distributor dan penerbitan buku perguruan tinggi dan umum. Perusahaan berdiri sejak 2010 dan memiliki 10 karyawan (media.neliti.com).

\section{Obyek Penelitian}

Obyek penelitiannya adalah pengelolaan konflik dalam perusahaan yang diduga berakibat pada overlapping tugas dan pekerjaan karyawan serta tingginya turn over karyawan pada dua tahun terakhir.

\section{Penentuan Informan Penelitian}

Informan penelitian ditentukan dengan cara purposive sampling yang dipilih berdasarkan fokus penelitian (sitiroikhanah.blogspot.com). Dalam penelitian ini, ada lima orang yang menjadi informan yaitu Pak Bayu sebagai pemilik perusahaan dan kedua adiknya sebagai pengelola perusahaan serta kedua karyawan yang paling lama bekerja di PT. Book Mart Indonesia.

\section{Jenis Data}

1. Data primer yaitu data yang dikumpulkan berdasarkan interaksi langsung antara peneliti dengan sumber utama penelitian (www.bphn.go.id).

2. Data sekunder, yaitu data yang dikumpulkan oleh pihak lain sebelumnya. Contoh data sekunder adalah dokumen (media.neliti.com).

\section{Prosedur Pengumpulan Data}

Data diperoleh dari melalui wawancara (indepth interview) maupun observasi yang ditangkap melalui indikator indikator aktifitas fisiknya, serta dokumentasi (www.bphn.go.id.

\section{Teknik Analisis Data}

1. Reduksi data

Proses pemilihan, penyederhanaan dan transformasi data kasar/mentah yang muncul dari catatan hasil observasi maupun hasil wawancara di lapangan.

2. Penyajian data, analisis data dan informasi. (docplayer.info)

Setelah data mengalami proses reduksi maka tersusun sekumpulan informasi yang disajikan selain dalam bentuk teks yang naratif, dapat juga berupa grafik, matriks, tabel, dan chart yang disertai proses interpretasi atas data maupun informasi.

3. Menarik (sitiroikhanah.blogspot.com).

kesimpulan/verifikasi

\section{Uji Keabsahan Data}

Agar dapat dipertanggung jawabkan, data informasi harus teruji keabsahannya. Untuk pelaksanaan uji keabsahan data dan informasi ini, Moleong dalam Leksono (2013:389) menjelaskan bahwa peneliti harus menyertakan subyek untuk: a) ikut memperbaiki temuan dan penafsiran. b) memberikan data dan informasi tambahan. c) membuka ruang subyek untuk menyetujui atau menolak data dan informasi tambahan, serta d) ikut memberikan penilaian deskripsi peneliti atas data dan informasi tentang kesesuaiannya dengan realita yang sebenarnya.

\section{HASIL PENELITIAN DAN PEMBAHASAN}

1. Tata kelola (good governance) perusahaan keluarga.

Prinsip-prinsip dalam Good Corporate Governance (docplayer.info) secara umum (Zarkasyi, 2008):

a. Transparansi: Secara sederhana bisa diartikan sebagai keterbukaan informasi. Dalam mewujudkan prinsip ini, perusahaan dituntut untuk menyediakan informasi yang cukup, akurat, tepat waktu kepada segenap stakeholders-nya.

b. Akuntabilitas: Yang dimaksud dengan akuntabilitas adalah kejelasan fungsi, struktur, sistem dan pertanggung jawaban elemen perusahaan.

c. Tanggung Jawab: Bentuk pertanggungjawaban perusahaan adalah kepatuhan perusahaan terhadap peraturan yang berlaku, diantaranya; masalah pajak, kesehatan, perlindungan lingkungan hidup, memelihara lingkungan bisnis yang 
kondusif bersama masyarakat dan sebagainya.

d. Kemandirian: Prinsip ini mensyaratkan agar perusahaan dikelola secara profesional tanpa ada benturan kepentingan dan tanpa tekanan atau intervensi dari pihak manapun yang tidak sesuai dengan peraturan-peraturan yang berlaku.

e. Kesetaraan: Prinsip ini menuntut adanya perlakuan yang adil dalam memenuhi hak stakeholder sesuai dengan peraturan perundangan yang berlaku (sullyhouse.blogspot.com) .

Berdasarkan penuturan subyek, aspek transparansi, akuntabilitas, tanggung jawab, kemandirian dan kesetaraan sudah diterapkan dengan baik dalam perusahaan ini hanya saja belum menjadi budaya organisasi artinya aktivitasaktivitas manajemen yang mengarah tercapainya keterbukaan informasi, kejelasan fungsi, struktur, sistem dan pertanggungjawaban elemen-elemen perusahaan belum dilaksanakan secara formal, belum menjadi habit perusahaan atau bahkan mungkin belum dilaksanakan secara sistemik. (eprints.undip.ac) (eprints.undip.ac.id).id).

\section{Keberlanjutan perusahaan}

Persaingan antar bisnis yang semakin ketat (docplayer.info) menuntut keberlanjutan perusahaan keluarga. Diperlukan strategi yang tepat untuk mempertahankan bisnis keluarga agar tetap menjawab tantangan era globalisasi. Perusahaan keluarga yang memiliki strategi keberlanjutan akan berdaya saing unggul sebab strategi keberlanjutan berdampak pada aktivitas perusahaan dan membentuk nilai di dalamnya. Lee dan Li (2009) menyatakan bahwa keberlanjutan perusahaan harus dipikirkan secara serius sejak didirikan sebab perusahaan keluarga rawan dengan keruntuhannya pada generasi kedua dan ketiga. Perusahaan keluarga harus mampu membaca jaman yang akan ditempuh ke depan, inilah yang kemudian tertuang dalam visi misi perusahaan. Penelitianpeneitian yang pernah dilakukan menunjukkan beberapa faktor yang mengukur keberlanjutan perusahaan. Pertama, keberlanjutan perusahaan keluarga dilihat dari kinerja. Menurut Andriani (2014), kinerja perusahaan adalah pencapaian perusahaan secara menyeluruh pada rentang waktu tertentu atau merupakan hasil dari aktivitas perusahaan dalam pengelolaan sumber daya yang dimiliki secara maksimal. Pencapaian-pencapaian ini bersandar pada target yang telah dibuat sebelumny atau proyeksi-proyeksi yang telah ditentukan dengan dasar pertanggungjawaban manajemen. Kausari (2014) menyatakan bahwa posisi unggul pasar akan dipegang oleh perusahaan yang melakukan pengawasan terhadap kinerja perusahaan secara konsisten. Kedua, keberlanjutan perusahaan diukur dari orientasi kewirausahaan perusahaan. Orientasi kewirausahaan ini berupa sikap proaktif, inovativ dan keberanian mengambil resiko. Pada perusahaan keluarga pondasi sikap-sikap ini diletakkan oleh generasi pendiri untuk diturunkan pada generasi di bawahnya, demikian seperti dinyatakan Quantananda dalam penelitiannya (2014). Faktor lain yang mempengaruhi keberlanjutan perusahaan keluarga adalah perencanaan suksesi. Perusahaan keluarga sangat rawan dalam persoalan kepemimpinan. Hal ini tak bisa lepas dari citra generasi pertama sebagai pendiri yang tak tergantikan, sehingga ketika perusahaan harus melakukan regenerasi dengan pergantian pimpinan maka kinerja perusahaan menurun. Berangkat dari hal ini, perencanaan suksesi harus disiapkan secara matang dengan melibatkan keluarga. Di antara hal yang harus diperhatikan adalah bahwa pimpinan pengganti harus dapat mengidentifikasi motivasi pendiri perusahaan, sedangkan pendiri perusahaan harus dapat mengidentifikasi kualifikasi generasi penerus sehingga ia layak memimpin atau tidak.

Terkait keberlanjutan perusahaan ini, berikut penuturan subyek:

Subyek 1). belum memikirkan persoalan suksesi karena dianggap perusahaan baru seumur jagung. Sedangkan subyek 2). mengatakan terus terang bahwa dia tidak mau dan tidak ingin menjadi pengganti subyek 1 untuk memimpin perusahaan ini. Ada pengakuan dari subyek 2 bahwa dia tidak memiliki interest pada buku. Subyek 5). cukup baik dalam memberikan pertimbangan tentang keberlanjutan perusahaan yaitu bahwa setiap aktivitas perusahaan harus dilaksanakan dengan tertib dan terdapat catatan agar dapat dievaluasi. Siapapun penerus perusahaan ini, tidak akan ada masalah jika sistem telah terbentuk dan terlaksana.

3. Konflik Keluarga

Susanto (2010) dalam tulisannya yang berjudul "Konflik Bisnis Perusahaan Keluarga" menjelaskan bahwa konflik dalam perusahaan keluarga didefinisikan sebagai situasi di mana terjadi perbedaan ide, pendapat dan pandangan yang berakibat pada perusahaan. Dari definisi ini, konflik dalam 
perusahaan keluarga dikelompokkan menjadi tiga yaitu konflikantara kepentingan bisnis dan keluarga,konflik antar anggota keluarga, dan konflik antara keluarga dan karyawan. Konflik antara kepentingan bisnis dan keluarga disebabkan adanya perbedaan nilai keluarga dan nilai bisnis. Konflik antar anggota keluarga contohnya konflik tujuan, gaya hidup dan pekerjaan, konflik terkait dengan kendali perusahaan dan konflik meninggalkan rumah. Konflik-konflik ini dapat mempengaruhi jalannya bisnis dalam perusahaan keluarga. Konflik antara keluarga dan karyawan terletak pada profesionalitas dan kepercayaan. Carlcok dan Ward menyatakan bahwa banyak keluarga menghindari untuk berkomunikasi dengan jujur tentang kondisi perusahaan yang sesungguhnya untuk menjaga keutuhan dalam keluarga.

Penuturan kelima subyek menunjukkan bahwa konflik keluarga memang dapat mempengaruhi bisnis perusahaan. Sedangkan konflik keluarga secara mendasar bisa disebabkan oleh tidak adanya visi dan misi yang jelas yang dijiwai oleh nilai-nilai keluarga yang diterapkan sebagai budaya organisasi dalam perusahaan. Untuk menghindari terjadinya konflik keluarga maka sejak awal pendiriannya, harus diletakkan pondasi yang jelas dan kuat yang kemudian dibangun di atasnya aturan-aturan organisasi. Subyek 4 dan 5 mengungkapkan secara sederhana bagaimana konflik dapat dikelola melalui pembagian kerja dan tugas yang jelas serta komunikasi terbuka di antara karyawan dan anggota keluarga. Hal yang paling penting adalah pembagian tugas dan gaji yang jelas.

Berdasarkan uraian di atas, permasalahan pengelolaan PT. Book Mart Indonesia dapat digambarkan melalui bagan berikut:

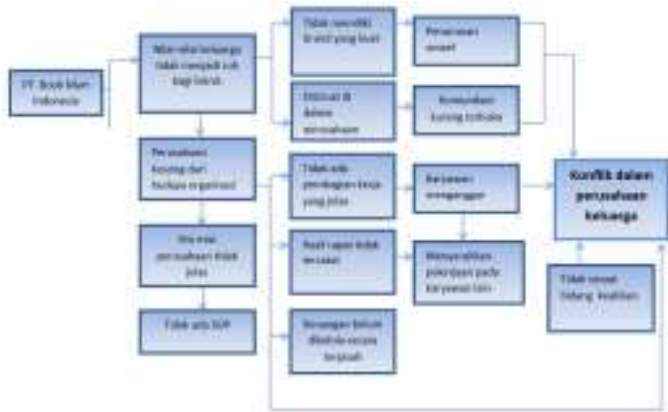

Gambar 1

Bagan Permasalahan Pengelolaan Konflik di PT. Book Mart Indonesia

\section{PENUTUP}

\section{Kesimpulan}

Berdasarkan penelitian yang telah dilakukan, makadapat disimpulkan bahwa:

1. Pengaruh konflik dalam Perusahaan keluarga di PT. Book Mart Indonesia.

Menurut temuan peneliti bahwa akar persoalan terjadinya konflik dalam PT. Book Mart Indonesia (PTBMI) adalah kosongnya perusahaan dari nilai-nilai keluarga, tidak ada budaya organisasi serta lemahnya visi misi sebagaimana telah dijelaskan dalam Bab IV. Konflik yang terjadi misalnya kesalahpahaman terkait informasi, keputusan terkait pengambilan proyek dan keputusan tentang pengalihan tugas/pembagian kerja. Konflik ini disebabkan oleh tidak adanya Standar Operational Procedure (SOP) karena visi misi yang lemah, tidak adanya aturan perusahaan yang jelas seperti sistem administrasi (pencatatan), pengelolaan keuangan profesional sampai penguatan brand di tengah-tengah pasar. Konflik ini berdampak besar dengan indikasi turn over karyawan yang tinggi serta menurunnya kinerja perusahaan.

2. Pengelolaan konflik dalam PT. Book Mart Indonesia

PTBMI merupakan perusahaan keluarga yang baru berdiri selama 8 tahun. Pondasi bisnisnya belum kuat karena tidak ada nilainilai keluarga yang menjiwai sehingga perusahaan juga tidak memiliki budaya organisasi dan dampaknya adalah visi misi perusahaan lemah. Salah satu akibat dari visi yang lemah adalah tidak adanya SOP sehingga pengelolaan setiap aktivitas bisnisnya masih dilakukan secara sederhana dan informal. Salah satu subyek mengakui bahwa tidak ada sistem pencatatan yang baik dalam perusahaan, akibatnya seringkali terjadi kesalah pahaman terhadap informasi yang diberikan pimpinan. Selama ini konflik masih ditangani secara sederhana dan belum diselesaikan dengan prosedur yang formal dan sistemik.

\section{Saran}

Bagi subyek penelitian:

1. Pimpinan PTBMI lebih memperhatikan nilainilai keluarga yang harus menjiwai visi misi sehingga perusahaan memiliki budaya organisasi yang dijadikan pedoman dalam menjalankan setiap aktivitas bisnis. Budaya organisasi ini akan mampu membantu pimpinan dalam memecahkan konflik dalam perusahaan. 
2. Nilai-nilai keluarga yang menjadi budaya organisasi akan melahirkan brand image yang kuat sehingga memantapkan posisi perusahaan di tengah-tengah pasar.

3. Pimpinan membuat SOP agar semua aktivitas bisnis terencana, dijalankan dan dievaluasi secara prosedural dengan target terukur.

4. SOP juga akan berfungsi untuk mengurangi mis informasi dan kesalah pahaman terkait tugas dan tanggung jawab setiap karyawan.

\section{DAFTAR PUSTAKA}

Dewi,A.C.E.and Dhewanto,W.2012.Key Success Fac-tors of Islamic Family Business. ProcediaS ocialand Behavioral Sciences57 (2012):53-60.

Eddleston, Kimberly A. 2010. Destructive and Productive Family Relationship:A Stewardship Theory Perspective. (shodhganga.inflibnet.ac.in)

Eddleston, Kimberly A. 2008. Planning for Growth: Life Stage Differences in Family Firms.EnterpreneurshipTheory and Practice (piz.san.edu.pl)

Helmiatin and Mulyana.2009.BisnisKeluarga http://www.ut.ac.id/html/suplemen/ekma41 11/ekma4111a/bisnis_keluarga.htm.October20 16. Diakses 15 Desember 2018

Hisrich,R.D.,Peters,M.P., and Shepherd,D.A.2008. Entrepreneurship Kewirausahaan.Edition 7. Jakarta:PenerbitSalembaEmpat.

Hnatek,M.2015.Entrepreneurial Thinkingas AKey FactorofFamilyBusinessSuccess. (www.researchgate.net) Procedia Social and BehavioralSciences181(2015):342-348.

Kementrian Koordinator Bidang Ekonomi Badan Statistik Perbankan Indoensia. 2017.

Laurence,L.and Mustamu,R.H.2015.Manajemen Konflik dalam Perencanaan Suksesi Perusahaan

Lambing, P.A. and Kuehl,C. R.2003.Entrepreneurship. Third Edition.New Jersey: Prentice Hall. (undana.ac.id)

Leksono, Sonny. 2013. Penelitian Ilmu Ekonomi Kualitatif Dari Metodologi ke Metode. Raja Grafindo Persada PT. Jakarta

Susanto, A. B. 2010. World Class Family Business. Membangun Perusahaan Keuarga Berkelas Dunia. Jakarta: (media.neliti.com) Penerbit Quantum Bisnis dan Manajemen

Simanjuntak, Agustinus. 2011. Jurnal Manajemen dan Kewirausahaan Vol. 12 No. 2 Hal. 113 120. Diakses 17 September 2018

Zaki, Achmad. Jurnal Aplikasi Manajemen (JAM). 2017. Diakses 16 September 2018

\section{Profil Penulis:}

1. Dian Rokhmawati

Universitas Wishnuwardhana Malang

Email : Yoke.barokahunited@gmail.com

\section{Rachma Yuliana}

Universitas Wishnuwardhana Malang

Email : Yoke.barokahunited@gmail.com 